важное прогностическое значение в плане снижения риска возникновения жизненно опасных нарушений сердечного ритма у пациентов с ишемической болезнью сердца и синдромом пролабирования митрального клапана.

Ключевые слова: ишемическая болезнь сердца, пролабирование митрального клапана, нарушения сердечного ритма, магний, Ритмокор.

\title{
DRUG CORRECTION OF CARDIAC ARRHYTHMIAS IN PATIENTS WITH CORONARY HEART DISEASE COMBINED WITH MITRAL VALVE PROLAPSE SYNDROME
}

\section{T.V. Naluzhna}

Abstract. The paper presents data of cardiac arrhythmias in patients with coronary heart disease combined with the mitral valve prolapse syndrome. In these patients were dominated Sinus tachycardia, atrioventricular extrasystole, atrial fibrillation, paroxysmal tachycardia predominated in such patients. It has been proposed to include to the basic therapy these patients such preparations of magnesium, in particular, a domestic preparation - Rythmocor, taking into account the principal mechanisms of the development of arrhythmias. The antiarrhythmic, antiischemic, membranostabilizing action of the drug has been corroborated. A positive impact of Rhythmocor on the magnesium levels in the blood and a reduction of the duration of the interval QT has also been noteds correction of the arrhythmic syndrome has an important prognostic value in terms of reducing the risk of the onset of cardiac arrhythmias dangerous to life in patients with coronary heart disease, which occurs with the mitral valve prolapse syndrome.

Key words: coronary artery disease, mitral valve prolapse, cardiac arrhythmia, magnesium, Rhythmocor.

SHEE National Medical University (Ivano-Frankivs'k)

Рецензент - проф. О.І. Волошин

Buk. Med. Herald. - 2013. - Vol. 17, № 2 (66). - P. 94-97

Надійшла до редакції 04.03.2013 року

(c) Т.В. Налужна, 2013

УДК 616-053.1:613.221:618.63

Ю.М. Нечитайло, І.С. Семань-Мінько, О.Г. Буряк

\section{СУЧАСНІ ОСОБЛИВОСТІ ГРУДНОГО ВИГОДОВУВАННЯ ДІТЕЙ ПЕРШОГО РОКУ ЖИТТЯ ТА ДОГЛЯДУ ЗА НИМИ}

Буковинський державний медичний університет, м. Чернівці

Резюме. У статті проведено аналіз принципів вигодовування дітей першого року життя, яких дотримуються сучасні матері. Обстежено 87 дітей віком до одного року, які перебували на грудному вигодовуванні. Показано, що підходи до вигодовування дітей та принципи уведення прикормів дещо відрізняються від між-

Вступ. За визначенням ВООЗ, грудне вигодовування - невід'ємна складова процесу відтворення, а також ідеальний спосіб вигодовування немовляти, незамінна біологічна й емоційна основа розвитку дитини. Вигодовування дітей раннього віку є важливою проблемою сучасної педіатрії та дитячої нутриціології. У той же час, вся світова спільнота висловлює занепокоєння тим, що велика кількість дітей грудного і раннього віку все ще не отримує адекватного вигодовування, і що їх харчування, розвиток, стан здоров'я ставиться під загрозу $[2,5,7]$.

Грудне вигодовування $\epsilon$ найкращим видом харчування дитини першого року життя $[1,3]$. Однак частота його застосування на терені міста $€$ недостатньою і становить 40-45 \%. Причинами переходу на штучне вигодовування найчастіше $€$ відмова матері від його продовження через обмеження іiі індивідуального функціонування або зме-

(C) Ю.М. Нечитайло, І.С. Семань-Мінько, О.Г. Буряк, 2013 народних рекомендацій по підтримці грудного вигодовування. Зазначені і проаналізовані основні труднощі, 3 якими стикається мати під час природного вигодовування дитини.

Ключові слова: грудний вік, природне вигодовування, дитяча нутриціологія.

ншення продукції молока через нераціональний режим годування. Крім того, режим годування може порушувати нормальний перебіг інших фізіологічних процесів - сну дитини та матері $[4,6]$.

Приєднання України до міжнародної практики вигодовування, запропонованої відповідними підрозділами ВООЗ та ЮНІСЕФ, зафіксовано відповідними наказами МО3 України та науковими рекомендаціями. Однак зміни, які відбулися в організації харчування дітей, у практиці взаємовідносин між матір'ю та дитиною недостатньо вивчені.

Мета дослідження. Дослідити сучасні тенденції вигодовування дітей першого року життя.

Матеріал і методи. Група обстежених дітей включала 87 дітей: 85 народжених у термін і двоє недоношених дітей, середній гестаційний вік дітей склав $38,8 \pm 0,12$ тижня (табл. 1). Антропометричні виміри при народженні відповідали серед- 
ньому перцентильному коридору для новонароджених.

Перше прикладання до грудей у доношених дітей відповідно до існуючих протоколів було в пологовому будинку в перші 30 хв після народження, тільки у двох недоношених дітей із масою менше 2500 г перше прикладання було пізніше однієї доби. Враховуючи значну різницю в тактиці вигодовування недоношених дітей, у подальшому ми в окремих видах аналізу виключили їх із бази даних. Всі доношені діти були виписані з пологового будинку на 5-6-ту добу.

Статистична обробка отриманих даних проведена на комп'ютері з використанням програм електронних таблиць Quatro Pro версія 6.0 (фірми Borland) та програма статистичної обробки фірми Statsooft-Statistika for Windows версія 5.11.

Результати дослідження та їх обговорення. Всі діти групи спостереження в пологовому будинку знаходилися в палатах спільного перебування 3 матір'ю і годувалися 10 і більше разів на добу. У перші тижні життя більшість дітей вигодовувалося за вимогою дитини, але наприкінці періоду новонародженості сформувався фіксований режим годувань 7-8 разів на добу, без нічної перерви на тривалий сон (табл. 2). У подальшому кількість годувань коливалася в межах 6-8 разів у першому кварталі та 4-7 - у другому. Причому нефізіологічна частота годувань 4 рази на добу була в дев'яти дітей, більша частина яких (четверо дітей (44\%) народилася 3 гестаційним віком 40-41 тиждень та масою тіла при народженні 4000-4200 г.

Корекція харчування, яка включає в себе регуляцію об'єму рідини, за рахунок допоювання дитини водою, додавання водо- та жиророзчинних вітамінів (уведення соків та додавання до прикормів рослинних і тваринних жирів), уведення додаткового білка (жовток яйця, сирок), мала певні особливості. Водою всі діти допоювалися 3 перших тижнів життя, отримуючи іiї в об'ємі, який не перевищував 50 мл на добу (табл. 3). Соки уводили всім дітям, в основному, після чотирьох місяців. Корекція білка не проводилася в жодної дитини, а додавання жиророзчинних вітамінів мало місце тільки в семи дітей у віці після шести місяців. В обстежених нами дітей не застосовувався, як донатор вітаміну D, риб'ячий жир, донедавна ще дуже популярний у батьків.

Дітям віком 4,5-5,5 місяця, молоко матері, незалежно від його кількості в неї, може не задовольняти всіх потреб дитячого організму через обмежений об'єм їжі, що перетравлюється в шлунку. Тому здоровим дітям починають уводити більш концентровану їжу (прикорм) за призначенням лікаря [3]. Перший прикорм у більшості випадків уводився дітям за рекомендацією і під спостереженням лікарів-педіатрів замість одного із грудних годувань у середині дня (між 13-ю та 17-ю годинами), формуючи за його допомогою майбутній обід немовляти. Другий та третій прикорми - це, відповідно, сніданок та підвечірок дитини у другому півріччі (табл. 4).

Першим прикормом у 79,3\% обстежених дітей представлений молочною кашею, переважно промислового виробництва. Домінувала манна каша, менший відсоток становили гречана та вівсяна каші, і найменше було каш, комбінованих із

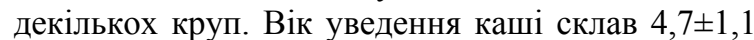
місяця, а об'єм прикорму в середньому був $146,6 \pm 6,3$ мл. Овочеве пюре, приготоване матіp'ю, було першим прикормом у 20,7 \% дітей,

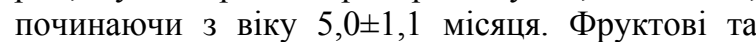
овочеві пюре промислового виготовлення давалися дітям у другому півріччі. У такому виборі першого прикорму спостерігаються сучасні особливості, пов'язані 3 доступністю та більшою простотою приготування швидкорозчинних збалансованих каш. Викликає занепокоєння склад другого прикорму, який також був представлений переважно молочними кашами або кашами із фруктово-овочевими добавками. Каші двічі на

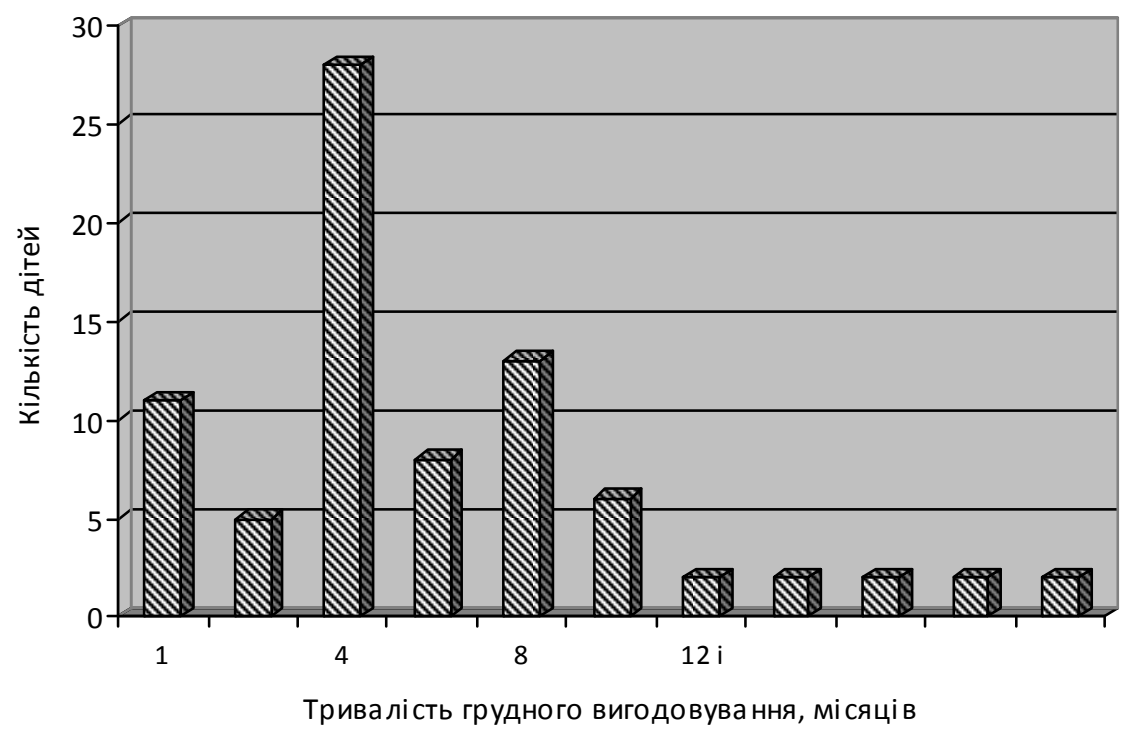

Рис. Тривалість вигодовування грудним молоком в обстеженій групі дітей 
Таблиця 1

Основні показники обстежених дітей при народженні

\begin{tabular}{|c|c|c|c|}
\hline \multirow{2}{*}{ Характеристика дітей } & \multicolumn{3}{|c|}{ Показник } \\
\cline { 2 - 4 } & Середній $(\mathrm{M} \pm \mathrm{m})$ & Мінімум & Максимум \\
\hline Гестаційний вік, тижні & $38,8 \pm 0,12$ & 34 & 41 \\
\hline Маса при народженні, г & $3403,7 \pm 54,3$ & 2100 & 60 \\
\hline Довжина тіла, см & $52,6 \pm 0,32$ & 43 & \\
\hline
\end{tabular}

Таблиця 2

Частота годувань на добу в обстежених дітей у різні вікові періоди

\begin{tabular}{|c|c|c|c|c|}
\hline \multirow{2}{*}{$\begin{array}{c}\text { № } \\
\text { п/п }\end{array}$} & \multirow{2}{*}{ Вік дітей } & \multicolumn{3}{|c|}{ Кількість годувань на добу } \\
\cline { 2 - 4 } & 1 місяць & середня & мінімум & максимум \\
\hline & 2 місяці & $7,6 \pm 0,27$ & 6 & 8 \\
\hline & 3 місяці & $7,6 \pm 0,21$ & 6 & 8 \\
\hline & 4 місяці & $7,7 \pm 0,19$ & 6 & 7 \\
\hline & 5 місяців & $6,7 \pm 0,16$ & 6 & 7 \\
\hline & 6 місяців & $6,4 \pm 0,42$ & 4 & 6 \\
\hline
\end{tabular}

Таблиця 3

Корекція харчування в обстежених дітей

\begin{tabular}{|c|c|c|c|c|}
\hline \multirow{2}{*}{$\begin{array}{c}\text { № } \\
\text { п/п }\end{array}$} & Вид корекції & \multicolumn{3}{|c|}{ Показник } \\
\cline { 3 - 5 } & Вода, вік уведення, міс. & середній & мінімум & максимум \\
\hline & Вода, об'єм у мл & $26,4 \pm 1,7$ & 1 & 50 \\
\hline & Соки, вік уведення, міс. & $4,8 \pm 0,18$ & 3 & 6 \\
\hline & Соки, об’єм у мл & $35,2 \pm 2,6$ & 10 & 60 \\
\hline
\end{tabular}

Таблиця 4

Вік уведення прикормів у обстежених дітей

\begin{tabular}{|c|c|c|c|c|}
\hline \multirow{2}{*}{$\begin{array}{c}\text { № } \\
\text { п/п }\end{array}$} & Вид прикорму & \multicolumn{3}{|c|}{ Вік дітей, місяці } \\
\cline { 3 - 5 } & Перший прикорм & середній & мінімум & максимум \\
\hline & Другий прикорм & $4,8 \pm 0,19$ & 3 & 6 \\
\hline & Третій прикорм & $5,4 \pm 0,26$ & 4 & 8 \\
\hline
\end{tabular}

день отримували двоє дітей. Такий вибір першого та другого прикорму в поєднанні $з$ пізньою корекцією соками та плодоовочевими пюре зменшує збалансованість їжі та зовнішнє надходження мінеральних речовин та заліза, дефіцит яких формується переважно у віці шести місяців.

У цілому, середня тривалість грудного вигодовування в групі обстежених дітей склала $6,7 \pm 0,8$ місяця. На рисунку наведено структуру цього показника по місяцях. Як видно з графіка, одинадцять дітей (12,6 \%) отримували природне вигодовування тільки один місяць. Найбільша кількість дітей вигодовувалася груддю матері впродовж чотирьох місяців (33,3 \%), майже $15 \%$ отримували молоко до восьми місяців, а після року грудне молоко у складі раціону отримували тільки поодинокі діти. 
Перехід на штучне чи змішане вигодовування в основному проводився самими мамами, без консультації з лікарем. Як замінники грудного молока в усіх дітей використовувалися адаптовані штучні суміші, що швидше всього є наслідком збільшення фінансової допомоги матерям на народження дитини та розширенням асортименту i покращання якості замінників грудного молока.

Догляд за дітьми передбачає, крім гігієнічних заходів, прогулянки 3 дітьми на свіжому повітрі, масаж, гімнастичні вправи, загартовування дитини тощо. Режим дня дитини раціонально організований у 57,5 \% дітей, це були переважно (більше $70 \%$ д) діти, які вигодовувалися за фіксованими годинами годування. Прогулянки на свіжому повітрі були щоденними і тривалістю не менше ніж 2 години у 56,3 \% дітей, менш тривалими і нерегулярними - у 25,3 \% та практично не гуляли 3 дітьми - 18,4\% батьків. Гімнастичні вправи своїм дітям регулярно проводили 50,7 \% батьків, зрідка це робили $22,9 \%$ і не займалися 3 дитиною в цьому напрямку - 26,4 \%. Масаж регулярно робили своїм дітям, переважно перед купанням, 47,1 \% батьків, не робили цього ніколи - 34,5 \%. Ще менше уваги приділялося батьками загартовуванню своїх дітей. Тільки 22,9 \% батьків користувалися загартовуванням за допомогою повітряних ванн, ніхто з батьків не використовував водних процедур.

Організація раціонального догляду за дитиною мала чіткі корелятивні зв'язки із соціальними показниками сім'ї. Так, спостерігалися позитивні кореляційні зв'язки адекватного догляду за дитиною $з$ рівнем освіти матері $(\Gamma=0,62 ; \mathrm{p}<0,05)$ та батька $(\Gamma=0,63 ; \mathrm{p}<0,05)$, матеріальними статками сім' $\dddot{i}(r=0,50 ; p<0,05)$. Негативною була кореляція між організацією режиму дня та кількістю старших дітей у сім'ї $(\Gamma=-0,39 ; \mathrm{p}<0,05)$. Причому організація режиму дня в більшому ступені торкалася проведення гімнастичних вправ ( $\Gamma=0,65$; $\mathrm{p}<0,05)$ та прогулянок $(\Gamma=0,59 ; \mathrm{p}<0,05)$, і не впливала на загартовування $(\Gamma=0,18 ; \mathrm{p}>0,05)$.

\section{Висновки}

1. За останні роки змінилася схема вигодовування дітей. Поряд 3 тим залишаються важливи- ми негативні мікросоціальні фактори, які слід враховувати, з метою зменшення їх негативних впливів.

2. У практиці сучасних матерів корекція харчування має наступні терміни уведення: водою проводиться 3 перших тижнів життя в об'ємі, який не перевищує 50 мл на добу; соками - в основному після чотирьох місяців у середньому об'ємі - 35,2 2,6 мл; корекція білка не проводилася в жодної дитини, а додавання продуктів із жиророзчинними вітамінами мало місце тільки в семи дітей у віці після шести місяців.

Терміни уведення прикормів $є$ більш ранніми, ніж у рекомендаціях протоколів по підтримці грудного вигодовування.

Перспективи подальших досліджень. Полягають у вивченні особливостей фізичного та психомоторного розвитку немовлят при грудному вигодовуванні в сучасних умовах.

\section{Література}

1. Абольян Л.В. Современные аспекты грудного вскармливания / Л.В. Абольян, С.В. Новикова // Педиатрия. Журнал им. Г.Н. Сперанского. - 2011. - Т. 90, № 1. C. $80-83$.

2. Захарова И.Н. Формирование кишечной микробиоты у детей первого полугодия жизни и характер вскармливания / И.Н. Захарова, Н.Г. Сугян, Ю.А. Дмитриева // Вопр. практ. педиатрии. - 2010. - Т. 5, № 5. C. $115-121$.

3. Нечитайло Ю.М. Нутриціологія дитячого віку / Нечитайло Ю.М. - Чернівці: БДМУ, 2008. - 208 с.

4. Bhutta Z.A. Scaling up breastfeeding in developing countries / Z.A. Bhutta, M. Labbok // Lancet. - 2011. Vol. 378, № 9789. - P. 378-380.

5. Fewtrell M.S. Breast-feeding and later risk of CVD and obesity: evidence from randomised trials / M.S. Fewtrell // ProcNutr. Soc. -2011 . - № 1. - P. 1-6.

6. Grieger J.A. Dietary patterns and breast-feeding in Australian children / J.A. Grieger, J. Scott, L. Cobiac // Public Health Nutr. - 2011. - № 23. - P. 1-9.

7. Owen C.G. Breast-feeding and cardiovascular risk factors and outcomes in later life: evidence from epidemiological studies / C.G. Owen, P.H. Whincup, D.G. Cook // ProcNutr. Soc. - 2011. - № 1. - P. 1-7.

\section{СОВРЕМЕННЫЕ ОСОБЕННОСТИ ГРУДНОГО ВСКАРМЛИВАНИЯ ДЕТЕЙ ПЕРВОГО ГОДА ЖИЗНИ И УХОДА ЗА НИМИ}

\section{Ю.Н. Нечитайло, И.С. Семань-Минько, А.Г. Буряк}

Резюме. В статье проведен анализ принципов вскармливания детей первого года жизни, которых придерживаются современные матери. Обследовано 87 детей в возрасте до одного года, которые находились на грудном вскармливании. Показано, что подходы к вскармливанию детей и принципы введения прикормов несколько отличаются от международных рекомендаций по поддержке грудного вскармливания. Указаны и проанализированы основные трудности, с которыми сталкивается мать во время естественного вскармливания ребенка.

Ключевые слова: грудной возраст, естественное вскармливание, детская нутрициология.

\section{MODERN FEATURES OF BREAST-FEEDING INFANTS OF THE FIRST YEAR OF LIFE AND CARE OF THEM}

\section{Yu.M. Nechytailo, I.S. Seman'-Min `ko, O.G. Buriak}

Abstract. The paper analyzes the principles of feeding infants of the first year of life, which modern mothers adhere to. A total of 87 infants aged under one year who were breast-fed have been examined. It is shown that the approaches to 100 
feeding children and introducing complementary feeding guidelines are somewhat different from the international recommendations on supporting breastfeeding. The main difficulties faced by the mother during natural breastfeeding an infant have been mentioned and analyzed.

Key words: infancy, breastfeeding, child nutrition.

Bukovinian State Medical University (Chernivtsi)

Рецензент - проф. Т.В. Сорокман
Buk. Med. Herald. - 2013. - Vol. 17, № 2 (66). - P. 97-101

Надійшла до редакції 16.01.2013 року

(C) Ю.М. Нечитайло, І.С. Семань-Мінько, О.Г. Буряк, 2013

УДК 616.12-008.331.1:616.16-039.13-07

І.А. Плеш, Л.І. Гайдич

\section{СТАН МІКРОЦИРКУЛЯТОРНОГО РУСЛА НІГТЬОВОГО ЛОЖА ВЕРХНІХ КІНЦІВОК ТА ЗМІНИ ЦЕНТРАЛЬНОГО ВЕНОЗНОГО ТИСКУ У ХВОРИХ НА ЕСЕНЦЙНУ ГІПЕРТЕНЗІЮ ІІ СТАДІЇ ЗАЛЕЖНО ВІД СТРУКТУРИ ДОБОВОГО РИТМУ АРТЕРІАЛЬНОГО ТИСКУ}

Буковинський державний медичний університет, м. Чернівці

\begin{abstract}
Резюме. У статті представлені особливості змін мікроциркуляції нігтьового ложа та центрального венозного тиску (ЦВТ) у хворих на есенційну гіпертензію II стадії залежно від різних варіантів добового ритму артеріального тиску. Виявлено обернену взаємозалежність між зростанням рівня ЦВТ та зменшенням питомої ваги функціонуючих капілярів у пацієнтів із низь-
\end{abstract}

Вступ. Збереження та зміцнення здоров'я населення значною мірою залежить від науковообгрунтованого вибору профілактичних заходів. На сьогодні в кардіології сформувалися три стратегії профілактики серцево-судинних хвороб популяційна, високого ризику і вторинної профілактики $[1,3,4,7,8,9]$. Для забезпечення стратегії високого ризику варто більше уваги приділяти діагностичним етапам в обстеженні пацієнтів ще до появи в них яскравих клінічних ознак захворювання та ураження органів-мішеней.

Щодо вторинної профілактики, а саме забезпечення корекції факторів ризику та лікування 3 метою запобігання ускладненням та передчасній смерті, слід віддати належне досвіду розвинених країн світу. Проаналізувавши всі три стратегії, актуальним $\epsilon$ i залишається стратегія високого ризику (первинна профілактика), яка потребує тісної співпраці лікаря та пацієнта на ранньому етапі діагностики.

Має значно вище прогностичне та діагностичне значення в перебігу есенційної гіпертензії (ЕГ) дослідження структури та функції капілярів, як ключової ланки мікроциркуляторного русла, в яких відбуваються кінцеві процеси метаболізму, дифузії, піноцитозу, фагоцитозу тощо [2]. Порушення функції капілярів при артеріальній гіпертензії можна вважати одним із основних елементів патології $[5,6]$. Знаючи особливості капіляропатії в динаміці розвитку захворювання, можливо

(c) І.А. Плеш, Л.І. Гайдич, 2013 ким (Non-dipper) та від‘ємним (Night-picker) добовим індексом артеріального тиску, що може бути використано як діагностичні критерії високого ризику можливих ускладнень есенційної гіпертензії.

Ключові слова: есенційна гіпертензія, мікроциркуляція, центральний венозний тиск.

обгрунтувати план профілактичних заходів у хворих на ЕГ.

Мета дослідження. Виявити та обгрунтувати ранні фактори ризику у хворих на есенційну гіпертензію II стадії за комплексної оцінки в них добового ритму артеріального тиску, мікроциркуляторного русла та змін центрального венозного тиску.

Матеріал і методи. Обстежено 85 хворих на ЕГ ІІ стадії (за класифікацією ВООЗ, 2010), які перебували на амбулаторному та стаціонарному лікуванні у Вузловій клінічній лікарні ст. Чернів-

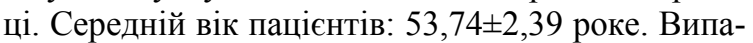
дковий рівень артеріального тиску (АТ) при надходженні до стаціонару в них становив: $162,53 \pm 2,31$ мм рт. ст. (систолічний - САТ) та $106,56 \pm 1,45$ мм рт. ст. (діастолічний - ДАТ).

Усім пацієнтам проводили добове моніторування АТ з використанням комплексу апаратури та програмного забезпечення АВРЕ-02 фірми «Solvaig» (Україна). Визначали центральний венозний тиск (ЦВТ) за методикою Вальдмана у нашій модифікації (посвідчення на раціоналізаторську пропозицію N42/03), проводили комп'ютерну капіляроскопію нігтьового ложа (ККСНЛ) верхніх кінцівок за допомогою цифрового оптичного капіляроскопа «Мікропоток» «MSX M7X camera» 3 програмним забезпеченням. Порівнювали дані за наступними ознаками - добовим індексом (ДІ) (dipper «D», non-dipper «ND», night- 